\title{
Microwave-Assisted Continuous Flow for the Selective Oligomerization of Glycerol +
}

\author{
Remi Nguyen ${ }^{1}$, Nicolas Galy ${ }^{1}$ and Christophe Len ${ }^{1,2, *}$ \\ 1 Sorbonne Universités, Université de Technologie de Compiegne, F-60203 Compiegne cedex, France; \\ nguyen.remi@rocketmail.com (R,N.); ngaly@laposte.net (N.G.) \\ 2 Chimie ParisTech, PSL University, CNRS, F-75005 Paris, France; \\ * Correspondence:Correspondence: christophe.len@chimieparistech.psl.eu; Tel.: +33-63-850-0976 \\ + Presented at the $1^{\text {st }}$ International Electronic Conference on Catalysis Sciences, 10-30 November 2020; \\ Available online: https://sciforum.net/conference/ECCS2020
}

Published: 10 November 2020

\begin{abstract}
The continuous oligomerisation of glycerol for the production of polyglycerol was carried out for the first time under microwave activation. Using potassium carbonate, a homogeneous commercial catalyst, various parameters like temperature, flow rate and residence time were studied. The main linear and branched-chain diglycerol and triglycerol regioisomers were characterized and the proportions of the different oligomers were quantified. A cyclic mode process was developed and short distance distillation allowed the mixture to be enriched with glycerol digesters and thus to obtain the following mixture: glycerol dimer (50.2 \% by weight), glycerol trimer $(22.1 \mathrm{wt} \%)$, glycerol tetramer $(9.5 \mathrm{wt} \%)$ and glycerol pentamer $(4.3 \mathrm{wt} \%)$.
\end{abstract}

Keywords: biomass; continuous flow; microwave; polymer

\section{Introduction}

Considering the programmed decrease in oil resources, chemical industry gives increasing attention to the concept of biorefinery [1-5]. In particular, the use of vegetable oils opens promising ways to valorize biomass and reach ecological future objectives [6-8]. Among the oilseed chemicals, glycerol is an outstanding example with great potential for conversion into valuable products. Glycerol has two primary hydroxyl groups and a secondary hydroxyl group with an axial symmetry. Hydroxyl groups have similar pKa and therefore close acid-base reactivity. Several chemical modifications obtained by esterification, etherification, oxidation, dehydration, hydrogenolysis, and oligomerization of glycerol have led to the production of many value-added chemicals. The products derived form that renewable resource had proven interesting in application fields like polymer, agrochemical and pharmaceutical industries [9-11].

Recently, alternative intensification processes such as continuous flow $[12,13]$ and microwave $[14,15]$ have been used and improved with the aim to develop sustainable and green processes. Among these, microwave-assisted continuous organic synthesis $[16,17]$ as a hybrid technology offers significant processing advantages over traditional batch chemistry like thermal control, conversion and mixture control, safety, adaptability to different reaction conditions, waste reduction, energy efficiency, continuous heterogeneous catalysis, easy scalability, and multi-step synthesis. The present work focuses on the efficient oligomerization of glycerol in a continuous microwave flow process.

\section{Experimental}

\subsection{Reagents}


Glycerol was obtained from Fisher chemicals. Bis(trimethylsilyl)acetamide (BSA) and potassium carbonate were obtained from Acros. No further purification was performed for all materials before utilization. Distilled water was used for oligomerization. Linear diglycerol, linear triglycerol and linear tetraglycerol were synthetized following synthesis previously described in the literature,[18,19] and used as standard for analysis.

\subsection{Microwave-assisted continuous oligomerization of glycerol}

A mixture of $240 \mathrm{~g}$ of glycerol $(2.61 \mathrm{~mol})$ and $10.0 \mathrm{~g}$ of potassium carbonate $(72.4 \mathrm{mmol})$ was magnetically stirred and heated in a $250 \mathrm{~mL}$ glass beaker until the basic catalyst is completely dissolved. A $2.45 \mathrm{GHz}$ microwave equipment, Miniflow 200SS manufactured by Sairem SAS (France) was, used with a Watson Marlow 520 peristaltic pump. The homogeneous mixture was into the coiled reactor $(54 \mathrm{~mL})$ including an irradiation cell $(20 \mathrm{~mL})$. The pump is set to appropriate flow rate and the target temperature of irradiation cell to $238^{\circ} \mathrm{C}$. After the beginning of collection an equilibration time is needed to reach a stationary regime ( $35 \mathrm{~min}$ at $1 \mathrm{~mL} \mathrm{~min}^{-1}, 70 \mathrm{~min}$ at $0.5 \mathrm{~mL} \mathrm{~min}-1,140 \mathrm{~min}$ at $\left.0.25 \mathrm{~mL} \mathrm{~min}^{-1}\right)$. Glycerol oligomers were quantified by gas chromatography analysis using calibration curves obtained from synthetized standards.

In cyclic mode, the reactor output was linked to the feeding beaker. After $250 \mathrm{~min}$, the reactor output was collected.

\subsection{Gas chromatography analysis}

PerkinElmer Gas Chromatography (Autosystem XL GC) apparatus is used to perform Gas chromatography analyses. We used an Altech AT HT column. FID detector temperature is set to $300{ }^{\circ} \mathrm{C}$,-injector temperature at $340{ }^{\circ} \mathrm{C}$, and a constant flow of nitrogen of $1 \mathrm{~mL} \mathrm{~min}^{-1}$ is applied. The temperature profile of the column is a preheating $150{ }^{\circ} \mathrm{C}$ for $2 \mathrm{~min}$, followed by an increase to $350{ }^{\circ} \mathrm{C}$ at $15{ }^{\circ} \mathrm{C} \mathrm{min}-1$, this temperature being maintained for $4.67 \mathrm{~min}$. Before injection, each sample is derivatized to decrease boiling points of oligomers. $0.5 \mathrm{~mL}$ of Bis(trimethylsilyl)acetamide (BSA) $(0.5$ $\mathrm{mL})$ were added to $40 \mathrm{mg}$ of sample $(40 \mathrm{mg})$ and the mixture is heated for $30 \mathrm{~min}$ at $50{ }^{\circ} \mathrm{C} .1 \mathrm{~mL}$ of ethyl acetate is added to the solution and $1 \mathrm{~mL}$ of the final solution is injected in the injector. We used Glycerol, linear diglycerol, triglyceriol and tetraglycerol as standard samples.[20]

\section{Results and discussion}

Oligomerisation of glycerol has been widely described through the use of different basic or acidic, homogeneous or heterogeneous catalysts. Continuing our previous work, $\mathrm{K}_{2} \mathrm{CO}_{3}$ as a homogeneous basic catalyst and glycerol (PG1) were chosen as this protocol can easily be carried out continuously. Oligomerisation was carried out using a continuous microwave intensification process using a commercial equipment (Sairem). A brief temperature study $\left(200^{\circ} \mathrm{C}-238^{\circ} \mathrm{C}\right)$ with a constant flow of $1.0 \mathrm{~mL} \mathrm{~min}^{-1}$ showed that a temperature lower than $230{ }^{\circ} \mathrm{C}$ did not allow an interesting conversion of glycerol and $238^{\circ} \mathrm{C}$ is the higher temperature allowed by the equipment.

Based on these results, variation of the flow $\left(0.25-1.0 \mathrm{~mL} \mathrm{~min}^{-1}\right)$ was studied at $238^{\circ} \mathrm{C}$ (Table 1$)$. In our hands, significant oligomerization is observed, particularly at low flow (0.25 vs $\left.1.0 \mathrm{~mL} \mathrm{~min}{ }^{-1}\right)$, with formation of many regiosisomers (PG2 and PG3) and cyclic products (cPG2). However, the conversion of glycerol (PG1) remains low because of a small reaction volume $(20 \mathrm{~mL})$ and consequently a short residence time. However, the longer the residence time the better the glycerol (PG1) conversion and the higher the yields of diglycerol (PG2), triglycerol (PG3) and tetraglycerol (PG4). With a reaction time four times longer, glycerol (PG1) conversion and diglycerol (PG2) yield are increased from $16 \%$ to $41 \%$ and from $12 \%$ to $22 \%$, respectively. Obviously, mixtures of dimer, trimer and tetramer include the corresponding regioisomers (PG2: $\alpha, \alpha$-diglycerol, $\alpha, \beta$-diglycerol, $\beta, \beta-$ diglycerol; PG3: $\alpha, \alpha-\alpha, \alpha$-diglycerol, $\alpha, \alpha-\beta, \alpha$-diglycerol, $\alpha, \alpha-\alpha, \beta$-diglycerol, $\alpha, \beta-\alpha, \beta$-diglycerol, $\beta, \alpha-$ $\alpha, \beta$-diglycerol, $\alpha, \alpha-\beta, \beta$-diglycerol, $\beta, \alpha-\beta, \beta$-diglycerol...) (Figure 1).

Table 1. Microwave-assisted continuous oligomerization of glycerol with peristaltic pump (GC analysis). ${ }^{1 .}$ 


\begin{tabular}{|c|c|c|c|c|c|c|c|}
\hline Entry & $\begin{array}{c}\text { Flow } \\
{\left[\mathrm{mL} \mathrm{min}^{-1}\right]}\end{array}$ & $\begin{array}{l}\text { Residence } \\
\text { time [min] }\end{array}$ & $\begin{array}{c}\text { PG1 } \\
{\left[w t^{\circ}\right]}\end{array}$ & $\begin{array}{c}\text { PG2 } \\
{[w t \%]}\end{array}$ & $\begin{array}{c}\text { PG3 } \\
{[w t \%]}\end{array}$ & $\begin{array}{c}\text { PG4 } \\
{[w t \%]}\end{array}$ & $\begin{array}{l}\text { Other } \\
\text { [wt\%] }\end{array}$ \\
\hline 1 & 1.0 & 20 & 84.0 & 12.1 & 2.4 & 0.2 & 0.4 \\
\hline 2 & 0.5 & 40 & 70.3 & 19.5 & 6.3 & 1.0 & 2.0 \\
\hline 3 & 0.25 & 80 & 59.1 & 22.1 & 9.3 & 4.4 & 5.0 \\
\hline
\end{tabular}

${ }^{1}$ Reaction conditions: $240 \mathrm{~g}$ of glycerol $(2.61 \mathrm{~mol}), 10.0 \mathrm{~g}$ of $\mathrm{K}_{2} \mathrm{CO}_{3}(72.4 \mathrm{mmol}), 238^{\circ} \mathrm{C}$, microwave in continuous flow.

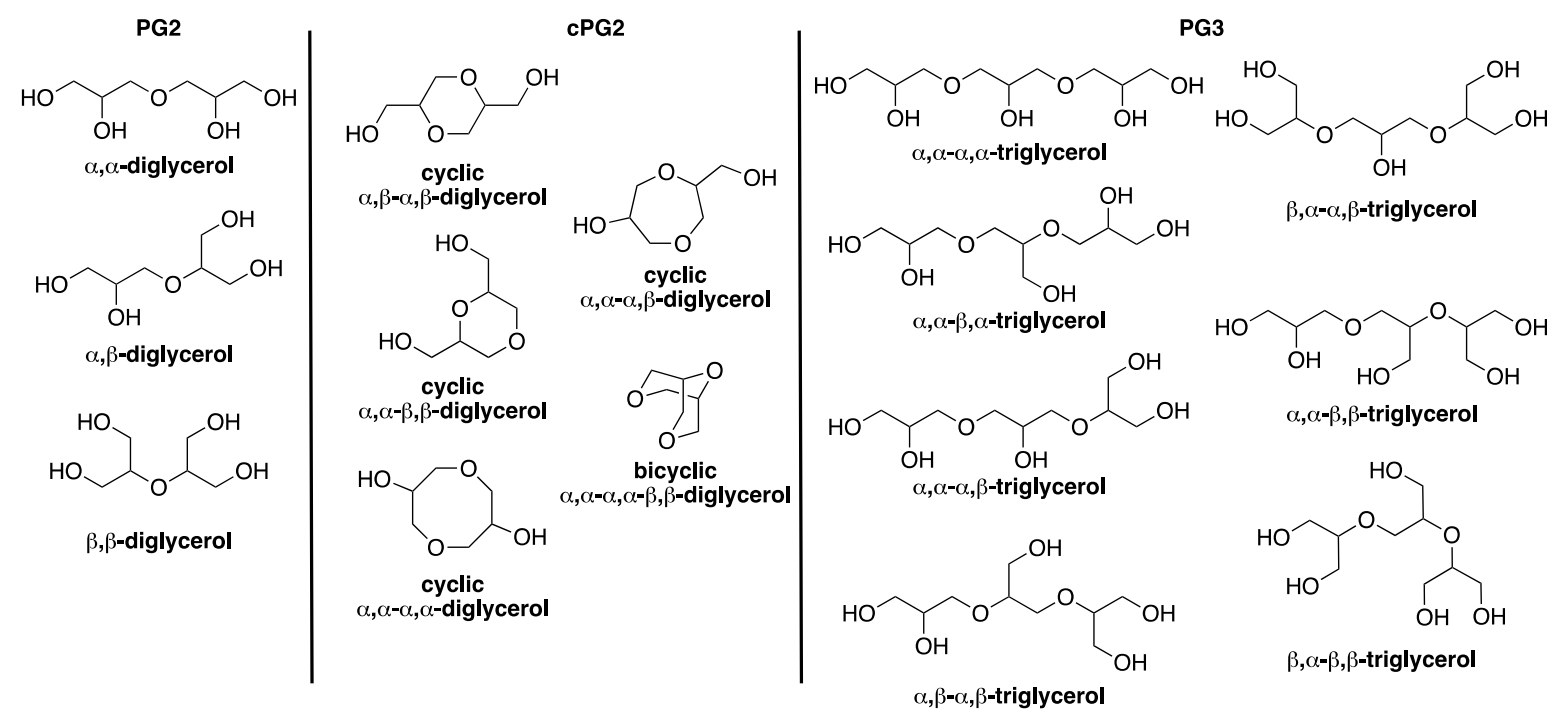

Figure 1. Different isomers of diglycerol (PG2) and triglycerol (PG3).

In order to increase the residence time while keeping the same equipment and specially the same reactor, the reaction mixture was re-injected to simulate a system with reactors in serial mode. These results suggest that while residence time controls glycerol conversion (Table 1), flow influences the distribution of oligomers with high flow favoring glycerol dimer over larger oligomers (Table 2).

Table 2. Microwave-assisted continuous oligomerization of glycerol with peristaltic pump in serial mode (GC analysis).1.

\begin{tabular}{|c|c|c|c|c|c|c|c|}
\hline Entry & $\begin{array}{c}\text { Flow } \\
{\left[\mathrm{mL} \mathrm{min}^{-1}\right]}\end{array}$ & $\begin{array}{l}\text { Residence } \\
\text { time [min] }\end{array}$ & $\begin{array}{c}\text { PG1 } \\
{[w t \%]}\end{array}$ & $\begin{array}{c}\text { PG2 } \\
{[w t \%]}\end{array}$ & $\begin{array}{c}\text { PG3 } \\
{[w t \%]}\end{array}$ & $\begin{array}{c}\text { PG4 } \\
{[w t \%]}\end{array}$ & $\begin{array}{l}\text { Other } \\
\text { [wt } \%]\end{array}$ \\
\hline 1 & 0.25 & 80 & 59.1 & 22.1 & 9.3 & 4.4 & 5.0 \\
\hline 2 & $0.5 \times 2$ & $40 \times 2$ & 58.4 & 26.0 & 9.3 & 3.5 & 2.8 \\
\hline
\end{tabular}

${ }^{1}$ Reaction conditions: $240 \mathrm{~g}$ of glycerol $(2.61 \mathrm{~mol}), 10.0 \mathrm{~g}$ of $\mathrm{K}_{2} \mathrm{CO}_{3}(72.4 \mathrm{mmol}), 238^{\circ} \mathrm{C}$, microwave in continuous flow.

To extend the result obtained in serial mode and to obtain better selectivity of the dimer (PG2), the process was used in cyclic mode (Figure 2). In these experimental conditions, there is no steady state as the composition of the solution changes at any time. Due to the variation in volume in our system (loss of water during the reaction), it is not possible to quantify the cycles. Therefore, only the reaction time was taken as a parameter to study the evolution of the composition of the solution during the reaction cycles (Table 3). With a flow rate of $0.5 \mathrm{~mL} \mathrm{~min}^{-1}$, the modification of the oligomer distribution is confirmed and a better selectivity of the dimer PG2 (26.4\% after $250 \mathrm{~min}$ vs $12.3 \%$ after $50 \mathrm{~min}$ ) has been obtained for a higher glycerol conversion. However, higher glycerol (PG1) conversion and higher diglycerol (PG2) formation as well leads to increased trimer (PG3) and tetramer (PG4) formation. 
<smiles>OCC(O)CO</smiles>

at $\mathrm{t}_{0}$, glycerol $(240 \mathrm{~g})$

and $\mathrm{K}_{2} \mathrm{CO}_{3}(10 \mathrm{~g})$

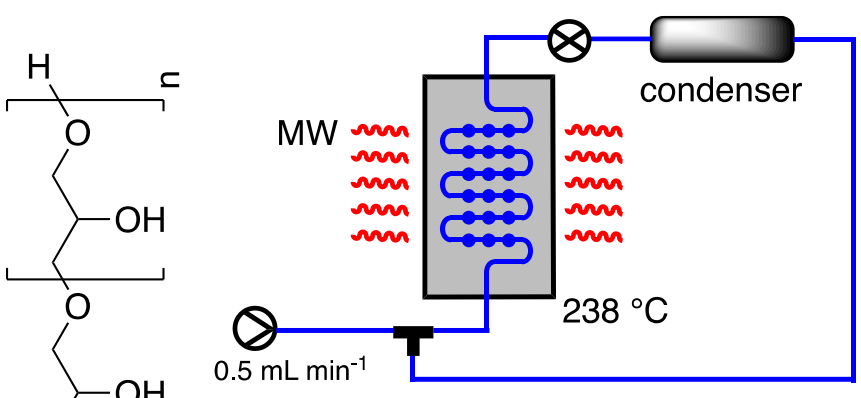

$\mathrm{OH}$

Figure 2. Cyclic microwave-assisted continuous oligomerization of glycerol.

Table 3. Microwave-assisted continuous oligomerization of glycerol with peristaltic pump in cyclic mode (GC analysis). ${ }^{1}$.

\begin{tabular}{|c|c|c|c|c|c|c|}
\hline Entry & $\begin{array}{l}\text { Time } \\
\text { [min] }\end{array}$ & $\begin{array}{c}\text { PG1 } \\
{[w t \%]}\end{array}$ & $\begin{array}{c}\text { PG2 } \\
{[\mathrm{wt} \%]}\end{array}$ & $\begin{array}{c}\text { PG3 } \\
\text { [wt \%] }\end{array}$ & $\begin{array}{c}\text { PG4 } \\
{[w t \%]}\end{array}$ & $\begin{array}{l}\text { Other } \\
{[w t \%]}\end{array}$ \\
\hline 1 & 50 & 85.9 & 12.3 & 1.5 & 0.2 & 0.1 \\
\hline 2 & 100 & 71.8 & 20.6 & 5.2 & 1.2 & 1.2 \\
\hline 3 & 150 & 62.1 & 25.5 & 7.9 & 2.3 & 2.2 \\
\hline 4 & 250 & 55.1 & 26.4 & 10.0 & 3.7 & 4.8 \\
\hline 5 & 250 & 55.2 & 24.2 & 9.2 & 3.4 & 7.4 \\
\hline
\end{tabular}

${ }^{1}$ Reaction conditions: $240 \mathrm{~g}$ of glycerol $(2.61 \mathrm{~mol}), 10.0 \mathrm{~g}$ of $\mathrm{K}_{2} \mathrm{CO}_{3}(72.4 \mathrm{mmol}), 238^{\circ} \mathrm{C}$, microwave in cyclic continuous flow.

In order to obtain a mixture of oligomers with a minimum amount of glycerol (PG1) and a maximum amount of diglycerol (PG2), short path evaporation has been performed at $150{ }^{\circ} \mathrm{C}$ under $0.1 \mathrm{mbar}$ (Table 4). The sample obtained after $250 \mathrm{~min}$ of cyclic microwave-assisted reaction at $238^{\circ} \mathrm{C}$ and $0.5 \mathrm{~mL} \mathrm{~min}^{-1}$ was evaporated and glycerol (PG1) and cyclic dimer (cPG2) were completely removed and no trace was detected in the residual fraction (Table 4, entry 3). Furthermore, an oligoglycerol enriched mixture containing 50\% diglycerol (PG2) is obtained.

Table 4. Short path evaporation of the crude product obtained after cyclic microwave-assisted oligomerization of glycerol (GC analysis).

\begin{tabular}{ccccccccccc}
\hline Entry & Fraction & $\begin{array}{c}\text { PG1 } \\
{[\mathbf{w t} \%]}\end{array}$ & $\begin{array}{c}\text { cPG2 } \\
{[\mathbf{w t} \%]}\end{array}$ & $\begin{array}{c}\text { PG2 } \\
{[\mathbf{w t} \%]}\end{array}$ & $\begin{array}{c}\text { cPG3 } \\
{[\mathbf{w t} \%]}\end{array}$ & $\begin{array}{c}\text { PG3 } \\
{[\mathbf{w t} \%]}\end{array}$ & $\begin{array}{c}\text { PG4 } \\
{[\mathbf{w t} \%]}\end{array}$ & $\begin{array}{c}\text { PG5 } \\
{[\mathbf{w t} \%]}\end{array}$ & $\begin{array}{c}\text { PG6 } \\
{[\mathbf{w t} \%]}\end{array}$ & $\begin{array}{c}\text { Other } \\
{[\mathbf{w t} \%]}\end{array}$ \\
\hline $1^{1}$ & Crude & 55.2 & 1.6 & 24.2 & 0.7 & 9.2 & 3.4 & 1.5 & 0.6 & 3 \\
$2^{2}$ & Distillate & 90 & 2.2 & 6.3 & 0.2 & 0.5 & - & - & - & 0.8 \\
$3^{2}$ & Residue & - & - & 50.2 & 2.0 & 22.1 & 9.5 & 4.3 & 2.0 & 7.4 \\
\hline
\end{tabular}

${ }^{1}$ Reaction conditions: $240 \mathrm{~g}$ of glycerol $(2.61 \mathrm{~mol}), 10.0 \mathrm{~g}$ of $\mathrm{K}_{2} \mathrm{CO}_{3}(72.4 \mathrm{mmol}), 238^{\circ} \mathrm{C}$, microwave in cyclic continuous flow.

\section{Conclusion}

Microwave-assisted continuous oligomerization of glycerol was developed in cyclic mode using commercial equipment (Sairem). Glycerol conversion is controlled by the residence time, the continuous flow has an impact on the distribution of oligomers, with smaller oligomers being obtained for higher flow. The optimized conditions ( $240 \mathrm{~g}$ of glycerol ( $2.61 \mathrm{~mol}), 10.0 \mathrm{~g} \mathrm{~K}_{2} \mathrm{CO}_{3}(72.4$ $\mathrm{mmol}$ ) at $238{ }^{\circ} \mathrm{C}$ under microwaves for $250 \mathrm{~min}, 0.5 \mathrm{~mL} \mathrm{~min}^{-1}$ ) afforded a glycerol conversion of $45 \%$ and a diglycerol selectivity higher than $26 \%$. After purification by short-distance evaporation, a $50 \%$ enriched dimer mixture is obtained without trace of glycerol and cyclic diglycerol. Further research 
with a larger reactor and higher power would allow more selective enriched oligoglycerol mixtures to be obtained.

Author Contributions: Conceptualization, C.L.; Methodology, R.N. and N.G.; Formal analysis, R.N. and N.G.; Writing - original draft preparation, R.N.; Writing - review and editing, C.L.; Supervision, C.L.

Funding: This research received no external funding.

Conflicts of Interest: The authors declare no conflict of interest.

\section{References}

1. Delbecq, F.; Khodadadi, M.R.; Padron, D.R.; Varma, R.S.; Len, C. Isosorbide: recent advances in catalytic production. Mol. Catal. 2020, 482, 110648.

2. Su, T.; Zhao, D.; Khodadadi, M.; Len, C. Lignocellulosic biomass for bioethanol: recent advances, technology trends and barriers to industrial development. Curr. Opin. Green Sustain. Chem. 2020, 24, 56-60.

3. Delbecq, F.; Wang, Y.; Muralidhara, A.; El Ouardi, K.; Marlair, G.; Len, C. Hydrolysis of hemicellulose and derivatives - A review of recent advances in the production of furfural. Front. Chem. 2018, 6, 146-174.

4. Wang, Y.; Zhao, D.; Padron, D.R.; Len, C. Recent advances in catalytic hydrogenation of furfural. Catalysts 2019, 9, 796-828.

5. Khodadadi, M.R.; Malpartida, I.; Tsang, C.W.; Lin, C.S.K.; Len, C. Recent advances on the catalytic conversion of waste cooking oil. Mol. Catal. 2020, 494, 111128.

6. Varma, R. S.; Len, C. Glycerol valorization under continuous flow conditions - Recent advances. Curr. Opin. Green Sustain. Chem. 2019, 15, 83-90.

7. Galy, N.; Nguyen, R.; Blach, P.; Sambou, S.; Luart, D.; Len, C. Glycerol oligomerization in continuous flow reactor. J. Ind. Eng. Chem. 2017, 51, 312-318.

8. Len, C.; Delbecq, F.; Corpas, C.C.; Ramos, E.R. Continuous flow conversion of glycerol into chemicals: an overview. Synthesis 2018, 50, 723-740.

9. Galy, N.; Nguyen, R.; Yalgin, H.; Thiebault, N.; Luart, D.; Len, C. Glycerol in subcritical and supercritical solvents. J. Chem. Technol. Biotechnol. 2017, 92, 14-26.

10. Gu, Y.; Jerome, F. Glycerol as a sustainable solvent for green chemistry. Green Chem. 2010, 12, 1127-1138.

11. Katryniok, B.; Paul, S.; Dumeignil, F. Recent developments in the field of catalytic dehydration of glycerol to acrolein. ACS Catal. 2013, 3, 1819-1834.

12. Wiles, C.; Watts, P. Continuous process technology: a tool for sustainable production. Green Chem. 2014, 16, $55-62$.

13. Vaccaro, L.; Lanari, D.; Marrochi, A.; Strappaveccia, G. Flow approaches towards sustainability. Green Chem. 2014, 16, 3680-3704.

14. Saggadi, H.; Luart, D.; Thiebault, N.; Polaert, I.; Estel, L.; Len, C. Toward the synthesis of 6hydroxyquinoline starting from glycerol via improved microwave-assisted modified Skraup reaction. Catal. Commun. 2014, 44, 15-18.

15. Saggadi, H.; Luart, D.; Thiebault, N.; Polaert, I.; Estel, L.; Len, C. Quinoline and phenanthroline preparation starting from glycerol via improved microwave-assisted modified Skraup reaction. RSC Adv. 2014, 4, 21456-21464.

16. Saggadi, H.; Polaert, I.; Luart, D.; Len, C.; Estel, L. Microwaves under is p⿶esessure for the continuous production of quinoline from glycerol. Catal. Today 2015, 255, 66-74.spe?

17. Polaert, I.; Estel; L.; Luart, D.; Len, C.; Delmotte, M. A new and original microwave continuous reactor under high pressure for future chemistry. AIChE J. 2017, 63, 192-199.

18. Cassel, S.; Debaig, C.; Benvegnu, T.; Chaimbault, P.; Lafosse, M.; Plusquellec, D.; Rollin, P. Eur. J. Org. Chem. 
2001, 875-896.

19. Iaych, K.; Dumarçay, S.; Fredon, E.; Gérardin, C.; Lemor, A.; Gérardin, P. J. Appl. Polym. Sci. 2011, 120, 2354-

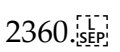

20. De Meuleaer, B.; Vanhoutte, B.; Huyghebaert, A. Development of chromatographic method for the determination of degree of polymerization of polyglycerol and polyglycerol fatty acid esters. Chromatographia 2000, 51, 44-52.

Publisher's Note: MDPI stays neutral with regard to jurisdictional claims in published maps and institutional affiliations.

(C) 2020 by the authors. Submitted for possible open access publication under the terms and conditions of the Creative Commons Attribution (CC BY) license (http://creativecommons.org/licenses/by/4.0/). 